\title{
Peritoneal carcinomatosis: limits of diagnosis and the case for liquid biopsy
}

\author{
James R.W. McMullen ${ }^{1}$, Matthew Selleck ${ }^{2}$, Nathan R. Wall ${ }^{1}$ and Maheswari Senthil ${ }^{2}$ \\ ${ }^{1}$ Department of Basic Sciences, Center for Health Disparities \& Molecular Medicine, Division of Biochemistry, Loma Linda \\ University Medical Center, Loma Linda, CA, USA \\ 2 Department of Surgery, Division of Surgical Oncology, Loma Linda University Medical Center, Loma Linda, CA, USA \\ Correspondence to: Nathan R. Wall, email: nwall@llu.edu
}

Maheswari Senthil, email: msenthil@llu.edu

Keywords: peritoneal carcinomatosis, liquid biopsy, biomarker, exosomes

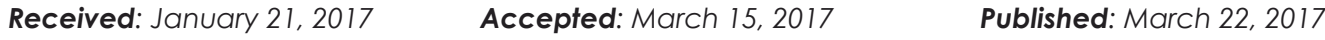

Copyright: McMullen et al. This is an open-access article distributed under the terms of the Creative Commons Attribution License 3.0 (CC BY 3.0), which permits unrestricted use, distribution, and reproduction in any medium, provided the original author and source are credited.

\section{ABSTRACT}

Peritoneal Carcinomatosis (PC) is a late stage manifestation of several gastrointestinal malignancies including appendiceal, colorectal, and gastric cancer. In PC, tumors metastasize to and deposit on the peritoneal surface and often leave patients with only palliative treatment options. For colorectal PC, median survival is approximately five months, and palliative systemic therapy is able to extend this to approximately 12 months. However, cytoreductive surgery with hyperthermic intraperitoneal chemotherapy (CRS/ HIPEC) with a curative intent is possible in some patients with limited tumor burden. In well-selected patients undergoing complete cytoreduction, median survival has been reported as high as 63 month. Identifying patients earlier who are either at risk for, or who have recently developed PC may provide them with additional treatment options such as CRS/HIPEC. PC is diagnosed late by imaging findings or often times during an invasive procedures such as laparoscopy or laparotomy. In order to improve the outcomes of PC patients, a minimally invasive, accurate, and specific PC screening method needs to be developed. By utilizing circulating PC biomarkers in the serum of patients, a "liquid biopsy," may be able to be generated to allow a tailored treatment plan and early intervention. Exosomes, stable patient-derived nanovesicles present in blood, urine, and many other bodily fluids, show promise as a tool for the evaluation of labile biomarkers. If liquid biopsies can be perfected in PC, manifestations of this cancer may be more effectively treated, thus offering improved survival.

\section{INTRODUCTION}

Peritoneal Carcinomatosis (PC) is a late stage manifestation of several gastrointestinal malignancies characterized by tumor deposition across the peritoneal surface [1]. This can be entirely asymptomatic in its early stages, or as the disease progresses, symptoms such as nausea, diarrhea, abdominal pain, bloating, and weight loss may develop [1]. The disease is often discovered when ascites or intestinal obstruction develop, occurring generally with greater tumor burden which is more difficult to treat [2]. Early PC detection when there is limited tumor burden may increase the effectiveness of current treatment options [3].

Colorectal cancer (CRC), the third most common cancer in the world, provides a good case study of PC. In 2016 there will be an estimated 95,270 cases of colorectal cancer in the United States and nearly 1.4 million cases worldwide [4]. Synchronous PC is diagnosed around the time of diagnosis of primary tumor while metachronous $\mathrm{PC}$ is diagnosed at a later time, typically months to years after the original diagnosis [5]. The incidence 
of synchronous isolated peritoneal carcinomatosis in patients with $\mathrm{CRC}$ varies somewhat in the literature from $4 \%-18 \%$ [6-9]. This may even be a low estimate given the lack of sensitivity of imaging for PC and that it may not be discovered until surgical exploration. Meanwhile, metachronous PC has been reported in 5-19\% of patients following definitive treatment.

\section{CYTOREDUCTIVE SURGERY (CRS)}

PC used to be considered a lethal disease with no curative surgical options. However, the growing acceptance of CRS with hyperthermic intraperitoneal chemotherapy (HIPEC), has offered the possibility of improved survival for carefully selected patients [3]. This method makes use of "cytoreduction" to surgically remove gross visible tumor deposits followed by direct contact of heated cytotoxic chemotherapy agents to affect any residual disease. Given during surgery, this protocol maximizes potential contact with the peritoneal surface while minimizing systemic toxicity. Specifically, hyperthermia between 41 and 43 degrees centigrade is combined with large molecular weight drugs that penetrate between a few cells deep to $3 \mathrm{~mm}$ causing cytotoxic effects [10]. Dr. Paul Sugarbaker is credited with developing this treatment option by combing these elements into a curative approach to peritoneal dissemination of gastrointestinal malignancies [11, 12]. Median survival of CRC PC without any treatment is approximately 4-7 months, while palliative systemic therapy may extend this to $12-23$ months based on several series [13-15]. Median overall survival with CRS/HIPEC has been reported to range from 22 to 63 months with a 5-year survival of $40-51 \%$ in selected patients $[13,15,16]$. The outcomes of CRS/ HIPEC are strongly influenced by careful patient selection and complete cytoreduction (CC-0) (see Table 1) [17]. Survival of patients with colorectal cancer who receive less than complete cytoreduction (CC-1 or CC-2) or have a higher burden of disease as indicated by the peritoneal carcinomatosis index (PCI) (see Figure 1) is significantly diminished compared to that of a CC-0 resection [17-19]. Extensive disease burden at identification often leaves patients with only palliative treatment options [20]. Despite the benefit of CRS/HIPEC, only about $25 \%$ of patients with $\mathrm{PC}$ will be eligible for this approach given the late presentation and burden of disease. In order to expand patient eligibility and offer treatment with a curative intent, early detection of $\mathrm{PC}$, before significant tumor burden develops, is essential.

\section{IMAGING}

Traditional imaging, such as CT and MRI lack sensitivity to both detect and estimate disease burden in PC. Classic computed tomography (CT) signs of PC such as "omental caking," thickening of the omentum, and peritoneal nodules are not common radiographic findings in "early" disease states. Several studies designed
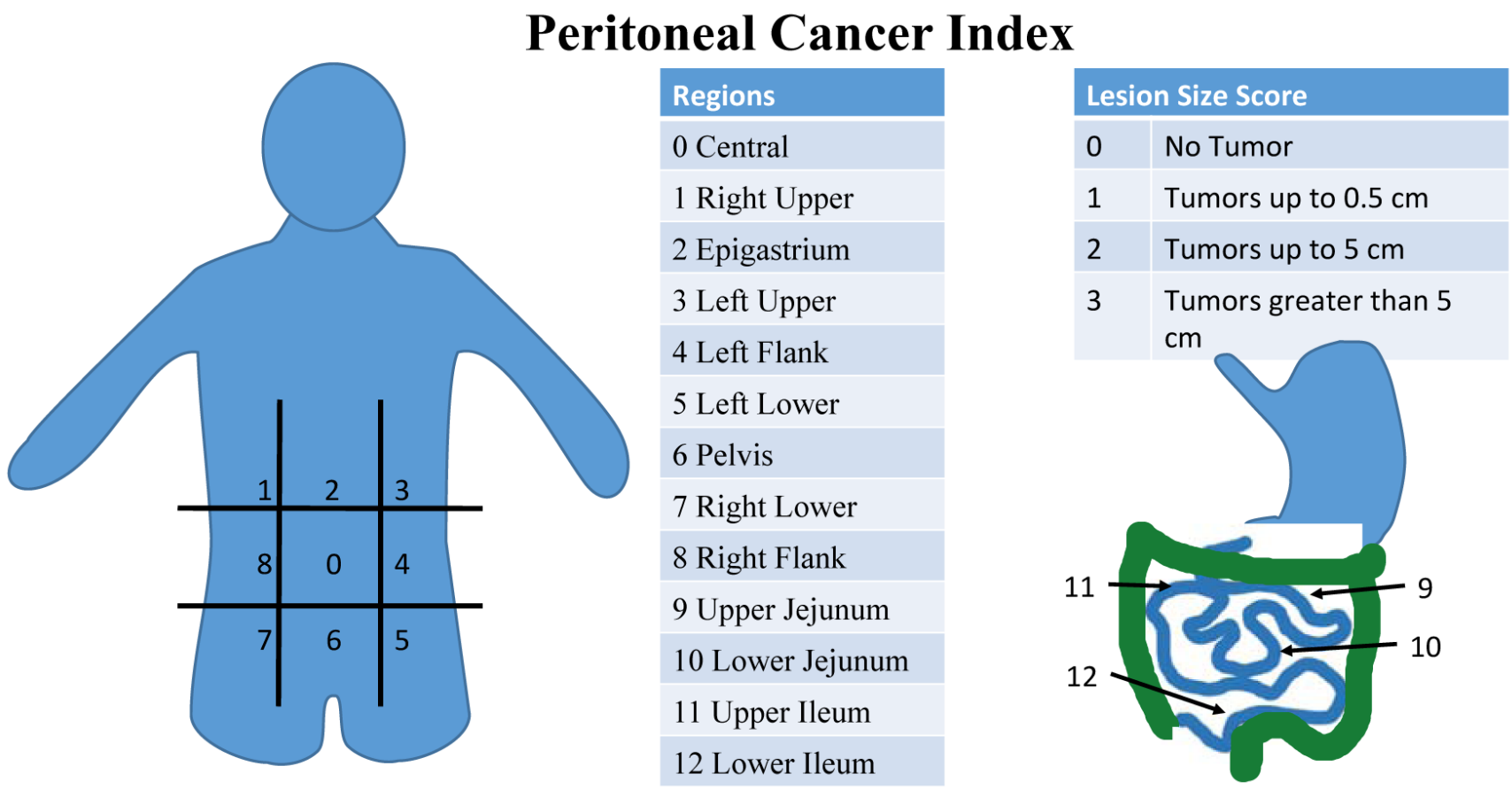

Figure 1: Peritoneal Cancer Index (PCI) scoring system. PCI is a diagnostic and prognostic tool that is a sum of scores in thirteen abdominal regions. Each receives a score of 0-3 based on the largest tumor size in each region. Scores range from 0 to 39 . Higher scores indicate more widespread and/or larger tumors in the peritoneal cavity. 
Table 1: CC is the completeness of cytoreduction score.

\begin{tabular}{|l|l|}
\hline \multicolumn{2}{|l|}{ Completeness of Cytoreduction scores } \\
\hline Score & Size of largest post-surgery residual tumor \\
\hline CC- 0 & No visible tumor \\
\hline CC- 1 & Less than $0.25 \mathrm{~cm}$ \\
\hline CC- 2 & Between $0.25 \mathrm{~cm}$ and $2.5 \mathrm{~cm}$ \\
\hline CC- 3 & $>2.5 \mathrm{~cm}$ or confluent \\
\hline
\end{tabular}

It indicates the size of the largest tumor that remains after cytoreductive surgery.

Table 2: This table summarizes the pros and cons of each non-invasive imaging modality in assessing PC

\begin{tabular}{|l|l|l|l|c|}
\hline \multicolumn{2}{|l|}{ Non-Invasive Imaging Utility in PC Detection } \\
\hline $\begin{array}{l}\text { Image } \\
\text { Modality }\end{array}$ & Pros & Cons & $\begin{array}{l}\text { Sensitivity/Specificity as } \\
\text { compared to surgical analysis }\end{array}$ & References \\
\hline Ultrasound & $\begin{array}{l}\text { Inexpensive, for } \\
\text { Effective for } \\
\text { ascites detection }\end{array}$ & $\begin{array}{l}\text { Limited PC nodule } \\
\text { sensitivity, highly operator } \\
\text { dependent }\end{array}$ & Non-specific [26] & {$[24,25]$} \\
\hline CT & $\begin{array}{l}\text { Standard staging } \\
\text { workup }\end{array}$ & $\begin{array}{l}\text { Limited small PC nodule } \\
\text { sensitivity, Inter-observer } \\
\text { variability }\end{array}$ & $\begin{array}{l}25-100 \% / 78-100 \% \text { with only 11- } \\
48 \% \text { sensitivity for tumors less } \\
\text { than 5 mm [26] }\end{array}$ & {$[18-21]$} \\
\hline MRI & $\begin{array}{l}\text { High } \\
\text { sensitivity } \quad P C\end{array}$ & $\begin{array}{l}\text { Relatively Expensive, slight } \\
\text { peristalsis motion artifact, } \\
\text { inter-observer variability }\end{array}$ & $\begin{array}{l}90 \% / 95.5 \% \text { diffusion weighted) }) \\
{[26]}\end{array}$ & {$[28]$} \\
\hline PET/ PET-CT & $\begin{array}{l}\text { High } \\
\text { sensitivity } \quad \text { PC }\end{array}$ & $\begin{array}{l}\text { Relatively Expensive, } \\
\text { Peristalsis motion artifact }\end{array}$ & $78-97 \% / 55-90 \%[26]$ & {$[27,28]$} \\
\hline
\end{tabular}

to determine the specificity and accuracy of CT scans in assessing tumor burden for PC found that CT significantly underestimated the amount of disease present in the peritoneal cavity [21-24]. Sensitivity for CT detection of tumor nodules less than $0.5 \mathrm{~cm}$ and $1 \mathrm{~cm}$ had been reported to be $11 \%$ and $25-50 \%$ respectively [23]. This is particularly important in colorectal PC, where PCI is a critical determinant of complete cytoreduction and long-term outcomes [25]. In a study by Koh et al looking specifically at CRC PC they determined CT significantly underestimated clinical PCI [23]. In fact sensitivity of small bowel involvement in each region ranged from $8-17 \%$. Despite this, the Fifth International Workshop on Peritoneal Surface Malignancy in Milan, identified CT as the principal imaging modality to assess suitability for CRS [26]. Ultrasound also has very limited sensitivity for detecting PC nodules [27-29]. Magnetic resonance imaging (MRI), and particularly diffusion weighted images, has been demonstrated in prospective studies to have increased accuracy in detection of carcinomatosis within certain areas of the abdomen [30]. This however carries its own limitations due to the motion artifacts of peristalsis, cost, and the need for radiologists trained in their interpretation and inter-observer variation. Additionally, positron emission technology (PET) may have increased sensitivity, but similar limitations and absence of added clinical value often precludes its use for determining resectability [24, 31-33]. These difficulties, especially limited sensitivity, lack of meaningful clinical correlation and high cost, reduce the utility of noninvasive imaging in the early detection of PC. With the current technology, laparoscopy or exploratory surgery is often necessary to confirm the diagnosis and extent of PC (see Table 2) [34].

\section{LIQUID BIOPSY}

Given the narrow subset of patients who are offered CRS/HIPEC, a potentially life-saving treatment, we are in need of a paradigm change. Patients who are either at risk for developing PC or who are in the earliest stage of this disease process may significantly benefit from expanded treatment options. The term "liquid biopsy" has reached prolific use as large-scale investigations seek to identify tumor markers in the serum. This usually refers to molecular diagnostic studies that are performed on blood or body fluid as opposed to cancerous tissue itself [35]. Multiple serum tumor markers: carcinoembryonic antigen (CEA), carbohydrate antigen CA 19-9, and CA 125, are commonly elevated in patients with PC and the degree of elevation tends to correlate with the extent of PC [36]. However, these serum tumor markers are inadequate for early detection of PC. Moreover, they lack specificity to predict the presence or risk of $\mathrm{PC}$ in patients with CRC. There is a critical clinical need to identify circulating tumor biomarkers of aggressiveness, likelihood of 
Table 3: These lung cancer associated miRs were discovered in both solid tumor and in tumor exosomes.

\begin{tabular}{|c|c|c|c|c|c|}
\hline miR-17-3p & miR-21 & miR-106a & miR-146 & miR-155 & miR-191 \\
\hline miR-192 & miR-203 & miR-205 & miR-210 & miR-212 & miR-214 \\
\hline
\end{tabular}

Table 4: Gastric Cancer PC associated exosomal miRs and their prevalence in various cancers.

\begin{tabular}{|c|c|c|c|c|c|c|c|}
\hline & Gastric Cancer & $\begin{array}{l}\text { Lung } \\
\text { Cancer }\end{array}$ & \begin{tabular}{|l|} 
Liver \\
Cancer
\end{tabular} & $\begin{array}{l}\text { Breast } \\
\text { Cancer }\end{array}$ & \begin{tabular}{|l|} 
Prostate \\
Cancer
\end{tabular} & $\begin{array}{l}\text { Colorectal } \\
\text { Cancer }\end{array}$ & Adrenal Cancer \\
\hline $\operatorname{miR} 1202$ & $\begin{array}{l}\text { ↔malignant ascites, } \\
\text { peritoneal } \\
\text { fluid, cell cuage } \\
{[52]}\end{array}$ & $\mathrm{x}$ & $\mathrm{X}$ & $\begin{array}{l}\uparrow \quad \text { serum } \\
\text { exosomes } \\
{[54]}\end{array}$ & $X$ & $\mathrm{X}$ & $\uparrow \varnothing$ tumor tissue [62] \\
\hline $\operatorname{miR}_{5 p} 1207-$ & $\begin{array}{|lr|}\leftrightarrow \text { malignant } & \text { ascites, } \\
\text { peritoneal } & \text { lavage } \\
\text { fluid, cell } & \text { culture } \\
{[52], \quad \downarrow t N m} & \text { tumor } \\
\text { tissue }[63], & \\
\downarrow \text { tumor tissue } & 64]\end{array}$ & $X$ & $\mid \begin{array}{lr}\downarrow & \text { solid } \\
\text { tumor }[56]\end{array}$ & $\mid \begin{array}{ll}\uparrow & \text { serum } \\
\text { exosomes } \\
{[54]}\end{array}$ & $\uparrow$ serum $[65]$ & 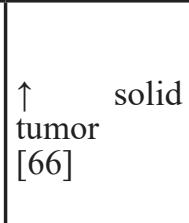 & $\mathrm{X}$ \\
\hline $\operatorname{miR}_{5 p} 1225-$ & \begin{tabular}{|l|}
$\uparrow$ tnM peritoneal \\
lavage fluid [52], \\
$\downarrow$ cancer tissue [53]
\end{tabular} & $x$ & $\begin{array}{l}\downarrow \text { blood } \\
{[67]}\end{array}$ & 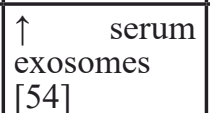 & \begin{tabular}{|l|}
$\uparrow$ blood [68], \\
$\downarrow$ solid tumor \\
{$[69]$}
\end{tabular} & $\begin{array}{l}\downarrow \\
\text { tumor }[70]\end{array}$ & $\begin{array}{l}\downarrow \text { multiple types of } \\
\text { solid tumors [71] }\end{array}$ \\
\hline $\operatorname{miR} 320 c$ & $\begin{array}{l}\leftrightarrow \text { malignant ascites, } \\
\text { peritoneal } \\
\text { fluid, cell cuage } \\
{[52]}\end{array}$ & $\begin{array}{l}\downarrow \quad \text { solid } \\
\text { tumor } \\
{[72]}\end{array}$ & $\mathrm{X}$ & $\mathrm{X}$ & $\mathrm{X}$ & $\mathrm{X}$ & $\mathrm{X}$ \\
\hline $\operatorname{miR} 4270$ & $\begin{array}{l}\leftrightarrow \text { malignant ascites, } \\
\text { peritoneal } \\
\text { fluid, cell culture } \\
{[52]}\end{array}$ & $X$ & $X$ & 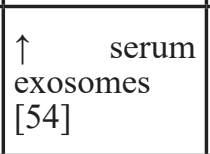 & $\mathrm{X}$ & $\mathrm{X}$ & $\mathrm{X}$ \\
\hline
\end{tabular}

All data is from human studies

$\uparrow, \downarrow$-increased/decreased expression associated with cancer

$\uparrow$ tnM, $\downarrow$ tnM -increased/decreased expression associated with metastatic cancer

$\uparrow \mathrm{tNm}, \downarrow \mathrm{tNm}$-increased/decreased expression associated with lymph node metastasis

$\uparrow \varnothing, \downarrow \varnothing$-increased/decreased expression associated with shorter patient survival

$\leftrightarrow$-present but no significant differential regulation

$\mathrm{X}$-no research discovered in literature

recurrence, risk of metastasis such as $\mathrm{PC}$, or even the presence of a malignancy to better tailor therapy for patients. For example, if a patient with a newly diagnosed stage III colorectal cancer is known to be at significant risk for peritoneal recurrence due to the presence of a specific set of biomarkers in their serum, they may benefit from prophylactic HIPEC. This is just one example of how this technology may be applied.

If blood-borne biomarkers for PC with high sensitivity and specificity are discovered, patients developing PC may be quickly identified with a blood test, a liquid biopsy. One such type of biomarker, microRNAs (miRs), short, non-coding RNAs that regulate mRNAs, has demonstrated diagnostic utility by correctly identifying several cancers of unknown primary with reasonable accuracy [37]. The diagnostic miR profile that was used in this study was generated from miR analysis in well differentiated primary tumors [37]. Several miRs, such as miR-21, have been linked to gastrointestinal cancers as potential diagnostic targets and prognostic indicators [38]. However these miRs and other types of RNAs are rapidly degraded in the plasma [39-41].

\section{EXOSOMES}

Exosomes, small cell-derived vesicles (Figure 2), can protect RNAs and miRNAs, from being degraded [4246]. When researchers exposed miRs to RNase, the miRs that were in exosomes and cells were protected while the free RNAs were degraded [42]. When exosomes were exposed to RNase the contained RNAs were protected from degradation while cellular RNA was degraded by the same RNase [45]. Exosomes hold great potential for both diagnosis and prognosis of diseases and are exceptionally useful as cancer biomarkers [47]. When a panel of lung cancer associated miRs was examined in solid tumors and tumor exosomes from patient plasma, most of the miRs were found to have highly comparable expression levels (see Table 3 for the miRs) [48, 49]. Cervical cancer cell line tumor derived exosomes (TEXs) contain survivin, which contributes to cancer aggressiveness and metastatic potential $[50,51]$. In a study of ovarian cancer, greater numbers of cancer exosomes were found in the serum as more advanced cancer stages were examined [52]. Furthermore, approximately four times more serum 
exosomes were discovered in lung cancer patients as compared to cancer free controls and the exosomes contained more than twice the miRs [48]. In our research, we found increased serum exosome levels in patients with prostate and breast cancers as compared to disease free controls [53-55]. TEXs are prevalent in patient serum from multiple cancer types and protect labile biomarkers from degradation [42, 45, 48, 53-55].

Exosomes have not been extensively studied in PC diagnostics. Andre and colleagues examined ascites exosomes from patients with PC and found that the tumor specific markers Her2/Neu, TRP1, and Mart1 were present in ascites tumor exosomes [56]. Tokuhisa and colleagues have identified several RNAs present in exosomes within peritoneal ascites, peritoneal lavage, and PC metastatic cell lines [57]. After exosome miR screening, 5 miRNAs were selected as a panel of significantly differentially regulated RNAs: miR 1202, 1207-5p, 1225-5p, 320c, and 4270 [57]. miR 21 had the strongest signal intensity in malignant ascites [57]. Exosomes from peritoneal lavage were probed for miR 21, 1225-5p, and 320c; miR 21 and $1225-5 p$ were found to be upregulated in later stages of gastric cancer and correlated with serosal invasion [57]. In a study on primary gastric cancer tissue, miR $1255-5 \mathrm{p}$ was generally downregulated and was found to inhibit cancer cell growth, motility, as well as cancer invasion [58]. This apparently contradictory result suggests that miR 1225$5 \mathrm{p}$ in peritoneal lavage either is being released by noncancerous tissue in an attempt to stop abnormal growths or is being used by cancers in order to facilitate better attachment to the peritoneum. In apparently contradictory results to the above study, in gastric cancer cell lines and in vivo, miR 1255-5p was generally downregulated and was found to inhibit cell growth and motility as well as cancer invasion [58].

The prospective gastric PC miR biomarkers described in the study by Tokuhisa and colleagues [57] have been found to be associated with other cancers as well (see Table 4). Notably, miR 1202, 1207-5p, 1225-5p, and 4270, were found circulating in the blood of breast cancer patients [59]. In human bladder cancer tissue samples, miR 320c was significantly downregulated [60]. In hepatocellular carcinoma tissue samples, miR 1207$5 \mathrm{p}$ was found to be significantly downregulated [61]. In adrenocortical carcinoma tissue samples, increased miR 1202 expression was found to be associated with significantly reduced patient lifespan [62]. The gaps in our knowledge of RNA signaling in cancer are immediately apparent from Table 4. The observation that these miRs, either individually or in a group, are associated with multiple types of cancer and are found in exosomes from the peritoneal cavity suggest the potential of exosomal diagnosis of PC.

\section{RNAS AND GASTRIC CANCER}

RNAs are found to be globally downregulated in cancer [37]. Upregulated RNAs and miRs are likely to be related to cancer growth and function or the body's response to cancer. miR 320c inhibited cell growth and motility in bladder cancer [60]. miR 1207-5p functioned to inhibit cell growth and invasion in liver cancer but

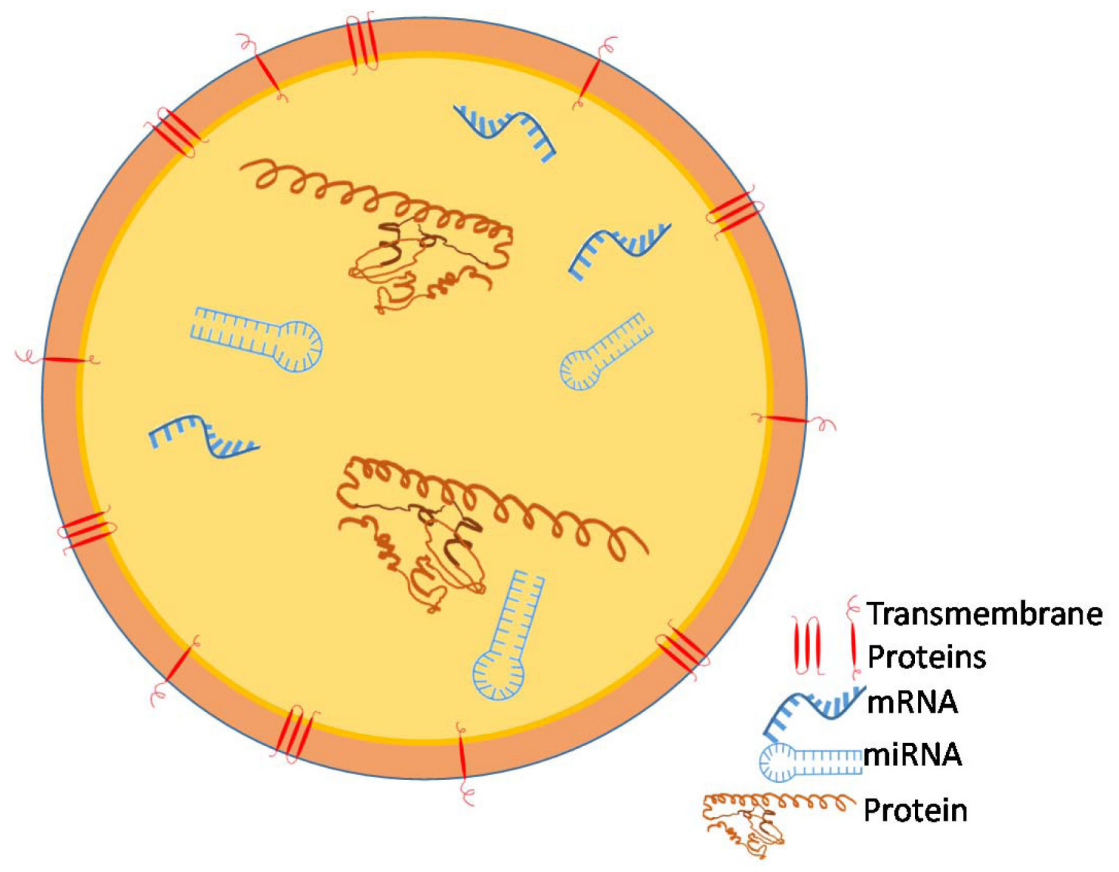

Figure 2: Tumor Cells release nanovesicles called exosomes which carry RNAs, including microRNAs and messenger RNAs, and proteins. 
functions to increase stemness in colorectal cancer [61, 63]. Since these exosomal-associated miRs have known functions in tumors, the possibility emerges of tailoring PC treatment based on what biomarkers are discovered in a patient's exosomes. miR 320c inhibited cell growth and motility and miR 1207-5p functioned to inhibit cell growth and invasion. The observation that these exosomalassociated miRs have known functions in tumors opens up the possibility of utilizing these biomarkers to tailor an individual patient's treatment. $[60,61]$

\section{FUTURE DIRECTIONS}

Additional research is needed to identify biomarkers in peritoneal carcinomatosis. Distinguishing metastatic disease of peritoneal origin from solid organ metastases should be both biologically feasible and clinically useful. As we look to exosomes to provide insight into the field, shared challenges in nanovesicle isolation and validation will need to be addressed. Reliable and efficient methods as well as recognized standards will need to be established for clinical use. Future clinical work in this field should include the prospective collection of samples for retrospective investigation. This will be instrumental in establishing clinical validity and utility. We are hopeful that the shared work of many will continue to yield advances in reducing the burden of life lost from this aggressive malady.

\section{CONCLUSIONS}

Recently, TEXs have been implicated in facilitating metastasis. TEXs can be taken up by multiple cell types, including endothelial cells, bone marrow progenitor cells, and other cancer cells [64-67]. These exosomes demonstrated the ability to deliver functional RNAs and proteins to recipient cells, modifying their growth patterns to be pro-oncogenic $[65,66]$. Further, TEXs have demonstrated the ability to greatly increase metastatic tumor burden in a mouse model [64]. Studying TEXs in the context of metastasis is a promising field. PC is currently difficult to detect at its onset. Late PC detection usually leaves the disease incurable. PC must be detected sooner for better patient outcomes. Non-invasive imaging is impractical for early PC detection. Detection of PC by means of markers within a patient's biofluids, such as a serum "liquid biopsy" would be ideal. Both serum and ascites contain biomarkers released by PC. Exosomes are released into serum by multiple types of cancers and protect their contents from degradation in the blood. These provide us with a likely source of a sensitive and specific diagnostic modality to detect PC in its earliest most treatable from.

\section{ACKNOWLEDGMENTS}

The authors would like to thank the Center for Health Disparities \& Molecular Medicine for its support. They would also like to thank members of the Wall Laboratory for careful review of this manuscript.

\section{CONFLICTS OF INTEREST}

The Authors declare no conflicts of interest.

\section{FUNDING}

Research reported in this publication was supported by NIH award P20MD006988 (NRW).

\section{REFERENCES}

1. Levy AD, Shaw JC, Sobin LH. Secondary Tumors and Tumorlike Lesions of the Peritoneal Cavity: Imaging Features with Pathologic Correlation. RadioGraphics. 2009; 29: 347-73. doi: 10.1148/rg.292085189.

2. Sadeghi B, Arvieux C, Glehen O, Beaujard AC, Rivoire M, Baulieux J, Fontaumard E, Brachet A, Caillot JL, Faure JL, Porcheron J, Peix JL, François Y, et al. Peritoneal carcinomatosis from non-gynecologic malignancies. Cancer. 2000; 88: 358-63. doi: 10.1002/(SICI)10970142(20000115)88:2 < 358::AID-CNCR16 > 3.0.CO;2-O.

3. Chia CS, You B, Decullier E, Vaudoyer D, Lorimier G, Abboud K, Bereder JM, Arvieux C, Boschetti G, Glehen O, Group tBIGR. Patients with Peritoneal Carcinomatosis from Gastric Cancer Treated with Cytoreductive Surgery and Hyperthermic Intraperitoneal Chemotherapy: Is Cure a Possibility? Annals of Surgical Oncology. 2016: 1-9. doi: 10.1245/s10434-015-5081-3.

4. Siegel RL, Miller KD, Jemal A. Cancer statistics, 2016. CA Cancer J Clin. 2016; 66: 7-30. doi: 10.3322/caac.21332.

5. Mekenkamp LJ, Koopman M, Teerenstra S, van Krieken JH, Mol L, Nagtegaal ID, Punt CJ. Clinicopathological features and outcome in advanced colorectal cancer patients with synchronous vs metachronous metastases. Br J Cancer. 2010;103:159-64. doi: 10.1038/sj.bjc.6605737.

6. Klaver YL, Lemmens VE, Nienhuijs SW, Luyer MD, de Hingh IH. Peritoneal carcinomatosis of colorectal origin: Incidence, prognosis and treatment options. World Journal of Gastroenterology. 2012; 18: 5489-94. doi: 10.3748/wjg. v18.i39.5489.

7. Klaver CE, Musters GD, Bemelman WA, Punt CJ, Verwaal VJ, Dijkgraaf MG, Aalbers AG, van der Bilt JD, Boerma D, Bremers AJ, Burger JW, Buskens CJ, Evers P, et al. Adjuvant hyperthermic intraperitoneal chemotherapy (HIPEC) in patients with colon cancer at high risk of peritoneal carcinomatosis; the COLOPEC randomized 
multicentre trial. BMC Cancer. 2015; 15. doi: 10.1186/ s12885-015-1430-7.

8. Mitry E, Guiu B, Cosconea S, Jooste V, Faivre J, Bouvier AM. Epidemiology, management and prognosis of colorectal cancer with lung metastases: a 30-year population-based study. Gut. 2010; 59: 1383-8. doi: 10.1136/gut.2010.211557.

9. Quere P, Facy O, Manfredi S, Jooste V, Faivre J, Lepage C, Bouvier AM. Epidemiology, Management, and Survival of Peritoneal Carcinomatosis from Colorectal Cancer: A Population-Based Study. Diseases of the Colon \& Rectum. 2015; 58: 743-52. doi: 10.1097/DCR.0000000000000412.

10. Yan TD, Cao CQ, Munkholm-Larsen S. A pharmacological review on intraperitoneal chemotherapy for peritoneal malignancy. World J Gastrointest Oncol. 2010; 2: 109-16. doi: 10.4251/wjgo.v2.i2.109.

11. Goodman MD, McPartland S, Detelich D, Saif MW. Chemotherapy for intraperitoneal use: a review of hyperthermic intraperitoneal chemotherapy and early postoperative intraperitoneal chemotherapy. J Gastrointest Oncol. 2016; 7: 45-57. doi: 10.3978/j.issn.20786891.2015.111.

12. Sugarbaker PH, Kern K, Lack E. Malignant pseudomyxoma peritonei of colonic origin. Natural history and presentation of a curative approach to treatment. Dis Colon Rectum. 1987; 30: 772-9.

13. Elias D, Lefevre JH, Chevalier J, Brouquet A, Marchal F, Classe JM, Ferron G, Guilloit JM, Meeus P, Goéré D, Bonastre J. Complete Cytoreductive Surgery Plus Intraperitoneal Chemohyperthermia With Oxaliplatin for Peritoneal Carcinomatosis of Colorectal Origin. Journal of Clinical Oncology. 2009; 27: 681-5. doi: 10.1200/ JCO.2008.19.7160.

14. Franko J, Shi Q, Goldman CD, Pockaj BA, Nelson GD, Goldberg RM, Pitot HC, Grothey A, Alberts SR, Sargent DJ. Treatment of Colorectal Peritoneal Carcinomatosis With Systemic Chemotherapy: A Pooled Analysis of North Central Cancer Treatment Group Phase III Trials N9741 and N9841. Journal of Clinical Oncology. 2012; 30: 263-7. doi: 10.1200/JCO.2011.37.1039.

15. Verwaal VJ, van Ruth S, de Bree E, van Sloothen GW, van Tinteren H, Boot H, Zoetmulder FA. Randomized Trial of Cytoreduction and Hyperthermic Intraperitoneal Chemotherapy Versus Systemic Chemotherapy and Palliative Surgery in Patients With Peritoneal Carcinomatosis of Colorectal Cancer. Journal of Clinical Oncology. 2003; 21: 3737-43. doi: 10.1200/ JCO.2003.04.187.

16. Chua TC. Progress in the combined modality management of peritoneal carcinomatosis. Journal of Surgical Oncology. 2010; 102: 728-9. doi: 10.1002/jso.21748.

17. Sugarbaker PH. Successful management of microscopic residual disease in large bowel cancer. Cancer Chemotherapy and Pharmacology. 1999; 43: S15-S25. doi: 10.1007/s002800051093.
18. Harmon RL, Sugarbaker PH. Prognostic indicators in peritoneal carcinomatosis from gastrointestinal cancer. International Seminars in Surgical Oncology. 2005; 2: 3. doi: 10.1186/1477-7800-2-3.

19. Verwaal VJ, van Ruth S, Witkamp A, Boot H, van Slooten G, Zoetmulder FA. Long-Term Survival of Peritoneal Carcinomatosis of Colorectal Origin. Annals of Surgical Oncology. 2004; 12: 65-71. doi: 10.1007/s10434-0041167-z.

20. Verwaal VJ, Kusamura S, Baratti D, Deraco M. The eligibility for local-regional treatment of peritoneal surface malignancy. Journal of Surgical Oncology. 2008; 98: 220-3. doi: 10.1002/jso.21060.

21. Dromain C, Leboulleux S, Auperin A, Goere D, Malka D, Lumbroso J, Schumberger M, Sigal R, Elias D. Staging of peritoneal carcinomatosis: enhanced CT vs. PET/CT. Abdominal Imaging. 2007; 33: 87-93. doi: 10.1007/s00261007-9211-7.

22. Esquivel J, Chua TC, Stojadinovic A, Melero JT, Levine EA, Gutman M, Howard R, Piso P, Nissan A, GomezPortilla A, Gonzalez-Bayon L, Gonzalez-Moreno S, Shen $\mathrm{P}$, et al. Accuracy and clinical relevance of computed tomography scan interpretation of peritoneal cancer index in colorectal cancer peritoneal carcinomatosis: A multiinstitutional study. Journal of Surgical Oncology. 2010; 102: 565-70. doi: 10.1002/jso.21601.

23. Koh JL, Yan TD, Glenn D, Morris DL. Evaluation of Preoperative Computed Tomography in Estimating Peritoneal Cancer Index in Colorectal Peritoneal Carcinomatosis. Annals of Surgical Oncology. 2008; 16: 327-33. doi: 10.1245/s10434-008-0234-2.

24. Low RN, Barone RM, Lucero J. Comparison of MRI and $\mathrm{CT}$ for predicting the Peritoneal Cancer Index (PCI) preoperatively in patients being considered for cytoreductive surgical procedures. Annals of Surgical Oncology. 2015; 22: 1708-15. doi: 10.1245/s10434-0144041-7.

25. da Silva RG, Sugarbaker PH. Analysis of prognostic factors in seventy patients having a complete cytoreduction plus perioperative intraperitoneal chemotherapy for carcinomatosis from colorectal cancer. J Am Coll Surg. 2006; 203: 878-86. doi: 10.1016/j.jamcollsurg.2006.08.024.

26. Baratti D, Kusamura S, Deraco M. The Fifth International Workshop on Peritoneal Surface Malignancy (Milan, Italy, December 4-6, 2006): methodology of disease-specific consensus. Journal of Surgical Oncology. 2008; 98: 25862. doi: 10.1002/jso.21056.

27. Repiso A, Gómez-Rodríguez R, López-Pardo R, Lombera MM, Romero M, Aranzana A, Abad S, Rodríguez-Merlo R, López L, Carboles JM. Usefulness of endoscopic ultrasonography in preoperative gastric cancer staging: diagnostic yield and therapeutic impact. Revista Española De Enfermedades Digestivas. 2010; 102: 413-20.

28. Savelli L, De Iaco P, Ceccaroni M, Ghi T, Ceccarini M, Seracchioli R, Cacciatore B. Transvaginal sonographic 
features of peritoneal carcinomatosis. Ultrasound in Obstetrics and Gynecology. 2005; 26: 552-7. doi: 10.1002/ uog.2587.

29. Patel CM, Sahdev A, Reznek RH. CT, MRI and PET imaging in peritoneal malignancy. Cancer Imaging. 2011; 11: 123-39. doi: 10.1102/1470-7330.2011.0016.

30. Fehniger J, Thomas S, Lengyel E, Liao C, Tenney M, Oto A, Yamada SD. A prospective study evaluating diffusion weighted magnetic resonance imaging (DW-MRI) in the detection of peritoneal carcinomatosis in suspected gynecologic malignancies. Gynecol Oncol. 2016; 142: 16975. doi: 10.1016/j.ygyno.2016.04.018.

31. De Vos N, Goethals I, Ceelen W. Clinical Value of (18) F-FDG- PET-CT in the Preoperative Staging of Peritoneal Carcinomatosis from Colorectal Origin. Acta Chirurgica Belgica. 2014; 114: 370-5.

32. Klumpp BD, Schwenzer N, Aschoff P, Miller S, Kramer U, Claussen CD, Bruecher B, Koenigsrainer A, Pfannenberg C. Preoperative assessment of peritoneal carcinomatosis: intraindividual comparison of 18F-FDG PET/CT and MRI. Abdominal Imaging. 2012; 38: 64-71. doi: 10.1007/s00261012-9881-7.

33. Low RN, Barone RM, Lacey C, Sigeti JS, Alzate GD, Sebrechts CP. Peritoneal tumor: MR imaging with dilute oral barium and intravenous gadolinium-containing contrast agents compared with unenhanced MR imaging and CT. Radiology. 1997; 204: 513-20. doi: 10.1148/ radiology.204.2.9240546.

34. Yonemura Y, Canbay E, Endou Y, Ishibashi H, Mizumoto A, Miura M, Li Y, Liu Y, Takeshita K, Ichinose M, Takao N, Hirano M, Sako S, et al. Peritoneal cancer treatment. Expert Opinion on Pharmacotherapy. 2014; 15: 623-36. doi: 10.1517/14656566.2014.879571.

35. Kin C, Kidess E, Poultsides GA, Visser BC, Jeffrey SS. Colorectal cancer diagnostics: biomarkers, cell-free DNA, circulating tumor cells and defining heterogeneous populations by single-cell analysis. Expert Review of Molecular Diagnostics. 2013; 13: 581-99. doi: 10.1586/14737159.2013.811896.

36. Wagner PL, Austin F, Sathaiah M, Magge D, Maduekwe U, Ramalingam L, Jones HL, Holtzman MP, Ahrendt SA, Zureikat AH, Pingpank JF, Zeh HJ, Bartlett DL, et al. Significance of Serum Tumor Marker Levels in Peritoneal Carcinomatosis of Appendiceal Origin. Annals of surgical oncology. 2013; 20. doi: 10.1245/s10434-012-2627-5.

37. Lu J, Getz G, Miska EA, Alvarez-Saavedra E, Lamb J, Peck D, Sweet-Cordero A, Ebert BL, Mak RH, Ferrando AA, Downing JR, Jacks T, Horvitz HR, et al. MicroRNA expression profiles classify human cancers. Nature. 2005; 435: 834-8. doi: 10.1038/nature03702.

38. Yin C, Zhou X, Dang Y, Yan J, Zhang G. Potential Role of Circulating MiR-21 in the Diagnosis and Prognosis of Digestive System Cancer: A Systematic Review and MetaAnalysis. Medicine (Baltimore). 2015; 94: e2123. doi: 10.1097/MD.0000000000002123.
39. Chen X, Ba Y, Ma L, Cai X, Yin Y, Wang K, Guo J, Zhang Y, Chen J, Guo X, Li Q, Li X, Wang W, et al. Characterization of microRNAs in serum: a novel class of biomarkers for diagnosis of cancer and other diseases. Cell Research. 2008; 18: 997-1006. doi: 10.1038/cr.2008.282.

40. Mitchell PS, Parkin RK, Kroh EM, Fritz BR, Wyman SK, Pogosova-Agadjanyan EL, Peterson A, Noteboom J, O'Briant KC, Allen A, Lin DW, Urban N, Drescher $\mathrm{CW}$, et al. Circulating microRNAs as stable blood-based markers for cancer detection. Proceedings of the National Academy of Sciences. 2008; 105: 10513-8. doi: 10.1073/ pnas.0804549105.

41. Tsui NB, Ng EK, Lo YM. Stability of Endogenous and Added RNA in Blood Specimens, Serum, and Plasma. Clinical Chemistry. 2002; 48: 1647-53.

42. Koga A, Aoyagi K, Imaizumi T, Miyagi M, Shirouzu K. Comparison between the Gastric Cancer Cell Line MKN45 and the High-Potential Peritoneal Dissemination Gastric Cancer Cell Line MKN-45P. The Kurume Medical Journal. 2011; 58: 73-9. doi: 10.2739/kurumemedj.58.73.

43. Pegtel DM, Cosmopoulos K, Thorley-Lawson DA, van Eijndhoven MA, Hopmans ES, Lindenberg JL, de Gruijl TD, Würdinger T, Middeldorp JM. Functional delivery of viral miRNAs via exosomes. Proceedings of the National Academy of Sciences of the United States of America. 2010; 107: 6328-33. doi: 10.1073/pnas.0914843107.

44. Skog J, Wurdinger T, van Rijn S, Meijer D, Gainche L, Sena-Esteves M, Curry WT, Carter RS, Krichevsky AM, Breakefield XO. Glioblastoma microvesicles transport RNA and protein that promote tumor growth and provide diagnostic biomarkers. Nature cell biology. 2008; 10: 14706. doi: 10.1038/ncb1800.

45. Valadi H, Ekström K, Bossios A, Sjöstrand M, Lee JJ, Lötvall JO. Exosome-mediated transfer of mRNAs and microRNAs is a novel mechanism of genetic exchange between cells. Nature Cell Biology. 2007; 9: 654-9. doi: 10.1038/ncb1596.

46. Cheng L, Sharples RA, Scicluna BJ, Hill AF. Exosomes provide a protective and enriched source of miRNA for biomarker profiling compared to intracellular and cellfree blood. J Extracell Vesicles. 2014; 3. doi: 10.3402/jev. v3.23743.

47. Khan S, Bennit HF, Wall NR. The emerging role of exosomes in survivin secretion. Histol Histopathol. 2015; 30: 43-50. doi: 10.14670/hh-30.43.

48. Rabinowits G, Gerçel-Taylor C, Day JM, Taylor DD, Kloecker GH. Exosomal MicroRNA: A Diagnostic Marker for Lung Cancer. Clinical Lung Cancer. 2009; 10: 42-6. doi: 10.3816/CLC.2009.n.006.

49. Yanaihara N, Caplen N, Bowman E, Seike M, Kumamoto K, Yi M, Stephens RM, Okamoto A, Yokota J, Tanaka T, Calin GA, Liu CG, Croce CM, et al. Unique microRNA molecular profiles in lung cancer diagnosis and prognosis. Cancer Cell. 2006; 9: 189-98. doi: 10.1016/j. ccr.2006.01.025. 
50. Khan S, Aspe JR, Asumen MG, Almaguel F, Odumosu O, Acevedo-Martinez S, De Leon M, Langridge $\mathrm{WH}$, Wall NR. Extracellular, cell-permeable survivin inhibits apoptosis while promoting proliferative and metastatic potential. Br J Cancer. 2009; 100: 1073-86. doi: 6604978 [pii] 10.1038/sj.bjc.6604978.

51. Khan S, Jutzy JM, Aspe JR, McGregor DW, Neidigh JW, Wall NR. Survivin is released from cancer cells via exosomes. Apoptosis. 2011; 16: 1-12. doi: 10.1007/s10495010-0534-4.

52. Taylor DD, Gercel-Taylor C. MicroRNA signatures of tumor-derived exosomes as diagnostic biomarkers of ovarian cancer. Gynecologic Oncology. 2008; 110: 13-21. doi: 10.1016/j.ygyno.2008.04.033.

53. Khan S, Bennit HF, Turay D, Perez M, Mirshahidi S, Yuan Y, Wall NR. Early diagnostic value of survivin and its alternative splice variants in breast cancer. BMC Cancer. 2014; 14: 176. doi: 10.1186/1471-2407-14-176.

54. Khan S, Jutzy JM, Valenzuela MM, Turay D, Aspe JR, Ashok A, Mirshahidi S, Mercola D, Lilly MB, Wall NR. Plasma-derived exosomal survivin, a plausible biomarker for early detection of prostate cancer. PLoS One. 2012; 7 : e46737. doi: 10.1371/journal.pone.0046737.

55. Turay D, Khan S, Diaz Osterman CJ, Curtis MP, Khaira B, Neidigh JW, Mirshahidi S, Casiano CA, Wall NR. Proteomic Profiling of Serum-Derived Exosomes from Ethnically Diverse Prostate Cancer Patients. Cancer Invest. 2016; 34: 1-11. doi: 10.3109/07357907.2015.1081921.

56. Andre F, Schartz NE, Movassagh M, Flament C, Pautier P, Morice P, Pomel C, Lhomme C, Escudier B, Le Chevalier $\mathrm{T}$, Tursz T, Amigorena S, Raposo $\mathrm{G}$, et al. Malignant effusions and immunogenic tumour-derived exosomes. Lancet. 2002; 360: 295-305.

57. Tokuhisa M, Ichikawa Y, Kosaka N, Ochiya T, Yashiro M, Hirakawa K, Kosaka T, Makino H, Akiyama H, Kunisaki C, Endo I. Exosomal miRNAs from Peritoneum Lavage Fluid as Potential Prognostic Biomarkers of Peritoneal Metastasis in Gastric Cancer. PLoS One. 2015; 10: e0130472. doi: 10.1371/journal.pone. 0130472 .

58. Zheng H, Zhang F, Lin X, Huang C, Zhang Y, Li Y, Lin J, Chen W, Lin X. MicroRNA-1225-5p inhibits proliferation and metastasis of gastric carcinoma through repressing insulin receptor substrate- 1 and activation of $\beta$-catenin signaling. Oncotarget. 2015; 7: 4647-63. doi: 10.18632/ oncotarget.6615.

59. Hamam R, Ali AM, Alsaleh KA, Kassem M, Alfayez M, Aldahmash A, Alajez NM. microRNA expression profiling on individual breast cancer patients identifies novel panel of circulating microRNA for early detection. Scientific Reports. 2016; 6: 25997. doi: 10.1038/srep25997.

60. Wang X, Wu J, Lin Y, Zhu Y, Xu X, Xu X, Liang Z, Li S, $\mathrm{Hu}$ Z, Zheng X, Xie L. MicroRNA-320c inhibits tumorous behaviors of bladder cancer by targeting Cyclin-dependent kinase 6. Journal of Experimental \& Clinical Cancer Research. 2014; 33: 69. doi: 10.1186/s13046-014-0069-6.
61. Zhao G, Dong L, Shi H, Li H, Lu X, Guo X, Wang J. MicroRNA-1207-5p inhibits hepatocellular carcinoma cell growth and invasion through the fatty acid synthasemediated Akt/mTOR signalling pathway. Oncology Reports. 2016; 36:1709-1. doi: 10.3892/or.2016.4952.

62. Özata DM, Caramuta S, Velázquez-Fernández D, Akçakaya P, Xie H, Höög A, Zedenius J, Bäckdahl M, Larsson C, Lui WO. The role of microRNA deregulation in the pathogenesis of adrenocortical carcinoma. EndocrineRelated Cancer. 2011; 18: 643-55. doi: 10.1530/ERC-110082 .

63. Farhana L, Antaki F, Anees MR, Nangia-Makker P, Judd S, Hadden T, Levi E, Murshed F, Yu Y, Van Buren E, Ahmed K, Dyson G, Majumdar AP. Role of cancer stem cells in racial disparity in colorectal cancer. Cancer Medicine. 2016; 5: 1268-78. doi: 10.1002/cam4.690.

64. Hoshino A, Costa-Silva B, Shen TL, Rodrigues G, Hashimoto A, Tesic Mark M, Molina H, Kohsaka S, Di Giannatale A, Ceder S, Singh S, Williams C, Soplop N, et al. Tumour exosome integrins determine organotropic metastasis. Nature. 2015; 527: 329-35. doi: 10.1038/ nature 15756.

65. Paggetti J, Haderk F, Seiffert M, Janji B, Distler U, Ammerlaan W, Kim YJ, Adam J, Lichter P, Solary E, Berchem G, Moussay E. Exosomes released by chronic lymphocytic leukemia cells induce the transition of stromal cells into cancer-associated fibroblasts. Blood. 2015; 126: 1106-17. doi: 10.1182/blood-2014-12-618025.

66. Peinado H, Aleckovic M, Lavotshkin S, Matei I, CostaSilva B, Moreno-Bueno G, Hergueta-Redondo M, Williams C, Garcia-Santos G, Ghajar C, Nitadori-Hoshino A, Hoffman C, Badal K, et al. Melanoma exosomes educate bone marrow progenitor cells toward a pro-metastatic phenotype through MET. Nat Med. 2012; 18: 883-91. doi: 10.1038/nm.2753.

67. Franzen CA, Simms PE, Van Huis AF, Foreman KE, Kuo PC, Gupta GN. Characterization of uptake and internalization of exosomes by bladder cancer cells. Biomed Res Int. 2014; 2014: 619829. doi: 10.1155/2014/619829.

68. Huang KH, Lan YT, Fang WL, Chen JH, Lo SS, Li AF, Chiou SH, Wu CW, Shyr YM. The Correlation between miRNA and Lymph Node Metastasis in Gastric Cancer. BioMed Research International. 2015; 2015. doi: $10.1155 / 2015 / 543163$.

69. Chen L, Lü MH, Zhang D, Hao NB, Fan YH, Wu YY, Wang SM, Xie R, Fang DC, Zhang H, Hu CJ, Yang SM. miR-1207-5p and miR-1266 suppress gastric cancer growth and invasion by targeting telomerase reverse transcriptase. Cell Death \& Disease. 2014; 5: e1034. doi: 10.1038/ cddis.2013.553.

70. Moltzahn F, Olshen AB, Baehner L, Peek A, Fong L, Stöppler H, Simko J, Hilton JF, Carroll P, Blelloch R. Microfluidic based multiplex qRT-PCR identifies diagnostic and prognostic microRNA signatures in sera of prostate cancer patients. Cancer research. 2011; 71: 550-60. doi: 
10.1158/0008-5472.CAN-10-1229.

71. Zhu J, Chen L, Zou L, Yang P, Wu R, Mao Y, Zhou H, Li R, Wang K, Wang W, Hua D, Zhang X. MiR-20b, -21 , and $-130 \mathrm{~b}$ inhibit PTEN expression resulting in B7-H1 over-expression in advanced colorectal cancer. Human Immunology. 2014; 75: 348-53. doi: 10.1016/j. humimm.2014.01.006

72. Fricke A, Ullrich PV, Heinz J, Pfeifer D, Scholber J, Herget GW, Hauschild O, Bronsert P, Stark GB, Bannasch H, Eisenhardt SU, Braig D. Identification of a blood-borne miRNA signature of synovial sarcoma. Molecular Cancer. 2015; 14. doi: 10.1186/s12943-015-0424-z.

73. Leidinger P, Hart M, Backes C, Rheinheimer S, Keck B, Wullich B, Keller A, Meese E. Differential blood-based diagnosis between benign prostatic hyperplasia and prostate cancer: miRNA as source for biomarkers independent of PSA level, Gleason score, or TNM status. Tumor Biology. 2016; 37: 10177-85. doi: 10.1007/s13277-016-4883-7.

74. He HC, Han ZD, Dai QS, Ling XH, Fu X, Lin ZY, Deng YH, Qin GQ, Cai C, Chen JH, Jiang FN, Liu X, Zhong WD. Global analysis of the differentially expressed miRNAs of prostate cancer in Chinese patients. BMC Genomics. 2013; 14: 757. doi: 10.1186/1471-2164-14-757.

75. Bartley AN, Yao H, Barkoh BA, Ivan C, Mishra BM, Rashid A, Calin GA, Luthra R, Hamilton SR. Complex Patterns of Altered MicroRNA Expression during the Adenoma-Adenocarcinoma Sequence for Microsatellite-
Stable Colorectal Cancer. Clinical cancer research. 2011; 17: 7283-93. doi: 10.1158/1078-0432.CCR-11-1452.

76. Velázquez-Fernández $\mathrm{D}$, Caramuta $\mathrm{S}$, Özata DM, Lu M, Höög A, Bäckdahl M, Larsson C, Lui WO, Zedenius J. MicroRNA expression patterns associated with hyperfunctioning and non-hyperfunctioning phenotypes in adrenocortical adenomas. European Journal of Endocrinology. 2014; 170: 583-91. doi: 10.1530/EJE-130817.

77. Lei $\mathrm{T}$, Zhu $\mathrm{Y}$, Jiang $\mathrm{C}$, Wang $\mathrm{Y}, \mathrm{Fu} J$, Fan Z, Qin H. MicroRNA-320 was downregulated in non-small cell lung cancer and inhibited cell proliferation, migration and invasion by targeting fatty acid synthase. Molecular Medicine Reports. 2016; 14: 1255-62. doi: 10.3892/ mmr.2016.5370. 